\title{
KAJIAN PERBEDAAN LAMA PENYINARAN DAN INTENSITAS CAHAYA TERHADAP PERTUMBUHAN SERTA SINTASAN BENIH IKAN TENGADAK Barbonymus schwanenfeldii
}

\author{
Mochamad Nurdin"), Kukuh Nirmala"', dan Ani Widiyati" \\ ") Balai Penyuluhan Pertanian, Perikanan dan Kehutanan VI Kabupaten Bogor \\ ") Fakultas Perikanan dan Ilmu Kelautan, Institut Pertanian Bogor \\ $\rightarrow$ Balai Penelitian dan Pengembangan Budidaya Air Tawar
}

(Naskah diterima: 22 April 2014; Revisi final: 9 Juli 2015, Disetujui publikasi: 2 September 2015)

\begin{abstract}
ABSTRAK
Lama penyinaran dan intensitas cahaya merupakan teknik sederhana manipulasi lingkungan untuk meningkatkan pertumbuhan dan sintasan ikan. Penelitian ini bertujuan untuk menentukan lama penyinaran dan intensitas cahaya yang terbaik terhadap pertumbuhan, serta sintasan benih ikan tengadak. Ikan uji

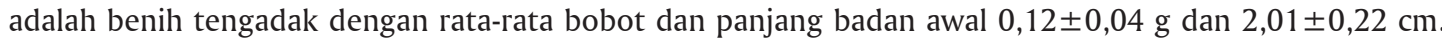
Ikan dipelihara dalam bak plastik $50 \mathrm{~L}$ sebanyak 50 ekor/bak dan diberi pakan tiga kali sehari. Intensitas cahaya yang berbeda dan penentuan lama penyinaran dengan automatic timer. Perlakuan terdiri atas (A1B1) lama penyinaran enam jam dan intensitas cahaya 250 lux, (A1B2) lama penyinaran enam jam dan intensitas cahaya 400 lux, (A1B3) lama penyinaran enam jam dan intensitas cahaya 550 lux, (A2B1) lama penyinaran 12 jam dan intensitas cahaya 250 lux, (A2B2) lama penyinaran 12 jam dan intensitas cahaya 400 lux, (A2B3) lama penyinaran 12 jam dan intensitas cahaya 550 lux, (A3B1) lama penyinaran 18 jam dan intensitas cahaya 250 lux, (A3B2) lama penyinaran 18 jam dan intensitas cahaya 400 lux, (A3B3) lama penyinaran 18 jam dan intensitas cahaya 550 lux. Setiap perlakuan dilakukan tiga kali ulangan. Hasil penelitian menunjukkan bahwa pertumbuhan dan sintasan benih ikan tengadak yang terbaik bila dipelihara pada lama penyinaran 12 jam dan intensitas cahaya 550 lux.
\end{abstract}

KATA KUNCI: lama penyinaran, intensitas cahaya, pertumbuhan, sintasan, Barbonymus schwanenfeldii

ABSTRACT: Study of different photoperiod and light intensity on growth and survival Tinfoil barb Barbonymus schwanenfeldii. By: Mochamad Nurdin, Kukuh Nirmala, and Ani Widiyati

Environmental manipulation such as photoperiod and light intensity will be able to increase the growth and survival of fish. This study aimed to determine the best of photoperiod and light intensity on the growth and survival of Tinfoil barb. Tinfoil barb with initial average of body weight and length of $0.12 \pm 0.04 \mathrm{~g}$ and $2.01 \pm 0.22 \mathrm{~cm}$ were used. Fish reared in the plastic tank with water volume of $50 \mathrm{~L}$ and stocked of 50 fish into each tank. Fish was fed commercial food for three times a day. White fluorescent lamp was used in order to adjust to light intensity and with completed by automatic timer. Factorial completely randomized design with two treatment factor was performed. The treatments of this experiment were as followed: (A1B1) photoperiod of six hours and 250 lux, (A1B2) photoperiod of six hours and 400 lux, (A1B3) photoperiod of six hours and 550 lux, (A2B1) photoperiod of 12 hours and 250 lux, (A2B2) photoperiod of 12 hours and 400 lux, (A2B3) photoperiod of 12 hours and 550 lux, (A3B1) photoperiod of 18 hours and 250 lux, (A3B2) photoperiod of 18 hours and 400 lux, (A3B3) photoperiod of 18 hours and 550 lux. Each treatment was consisted of three replicates. The results showed that growth and survival Tinfoil barb the best performances at photoperiod of 12 hours and 550 lux was found.

KEYWORDS: $\quad$ photoperiod, light intensity, growth, survival, Barbonymus schwanenfeldii

\# Korespondensi: Balai Penyuluhan Pertanian, Perikanan dan Kehutanan VI Kabupaten Bogor. Jl. Rangga Mekar, Bogor, Indonesia.

E-mail: mochamadnurdin38@yahoo.co.id 


\section{PENDAHULUAN}

Ikan tengadak Barbonymus schwanenfeldii merupakan jenis ikan endemik yang berasal dari Kalimantan dan Sumatera, habitatnya di sungai sedang, sungai besar, maupun rawa banjiran (Huwoyon et al., 2010). Ikan tengadak yang dikenal dengan kapiat dijadikan sebagai salah satu komoditas ikan hias, namun berpotensi untuk dibudidayakan sebagai ikan konsumsi. Pembudidayaan dilakukan di kolam atau keramba jaring apung untuk pelestarian di perairan (Widiyati et al., 2012). Untuk mendukung budidaya ikan tersebut sangat dibutuhkan teknologi produksi benih secara massal dan berkesinambungan.

Salah satu manipulasi lingkungan untuk meningkatkan pertumbuhan dan sintasan ikan adalah dengan manipulasi lama penyinaran dan intensitas cahaya (Boeuf \& Le Bail, 1999). Pada ikan Gilthead seabream Sparus aurata L., waktu penyinaran dalam waktu yang lebih lama dapat meningkatkan pertumbuhan, serta efisiensi pakan (Vardar \& Yildirim, 2012), meningkatkan sintasan benih Mirror carp Cyprinus carpio (Yagci \& Yigit, 2009) dan Rainbow trout Oncorhynchus mykiss (Erguin et al., 2003; Sonmez et al., 2009; Barimani et al., 2013). Selain itu, lama penyinaran juga dapat meningkatkan perkembangan renang larva Atlantic salmon Salmo salar L. (Martin et al., 2012), tingkat melatonin Lipped barb Osteochilus hasselti C.V (Prayogo et al., 2012), pematangan gonad Atlantic cod Gadus morhua L. (Karlsen et al., 2006) dan Goldfish Carassius auratus (Sarkar \& Upadhyay, 2011). Sedangkan pada ikan nokturnal, lama penyinaran yang diminimalkan dapat meningkatkan pertumbuhan, efisiensi pakan, serta warna tubuh pada benih African catfish Clarias gariepinus (Musthapha et al., 2012), memengaruhi jumlah sel darah dan menurunkan stres pada Clarias batrachus (Srivastava \& Choudhary, 2010).

Kemampuan ikan untuk tertarik pada sumber cahaya berbeda-beda. Cahaya dengan segala aspek yang dikandungnya seperti intensitas dan panjang gelombang akan memengaruhi secara langsung maupun tidak langsung pergerakan atau tingkah laku ikan. Ada ikan yang menyukai pada intensitas cahaya rendah, tetapi ada juga ikan yang menyukai intensitas cahaya tinggi (Boeuf \& Le Bail, 1999). Berdasarkan hasil penelitian Karakatsouli et al. (2010), Mirror common carp Cyprinus carpio pada intensitas cahaya 150 lux dan 300 lux tidak menunjukkan pertumbuhan yang signifikan.

Teknik manipulasi lama penyinaran dan intensitas cahaya diduga dapat diterapkan untuk meningkatkan produktivitas ikan. Namun kajian mengenai pengaruh lama penyinaran dan intensitas cahaya terhadap pertumbuhan, serta sintasan ikan belum dilakukan pada pendederan ikan tengadak. Oleh karena itu, penelitian ini bertujuan untuk menentukan lama penyinaran dan intensitas cahaya yang terbaik terhadap pertumbuhan dan sintasan benih ikan tengadak $B$. schwanenfeldii.

\section{BAHAN DAN METODE}

Penelitian ini dilaksanakan pada bulan September hingga Oktober 2013 di Instalasi Penelitian Lingkungan Perikanan Budidaya dan Toksikologi, Balai Penelitian dan Pengembangan Budidaya Air Tawar. Ikan uji adalah benih ikan tengadak Barbonymus schwanenfeldii dengan bobot dan panjang badan awal 0,12 $\pm 0,04 \mathrm{~g}$ dan $2,01 \pm 0,22 \mathrm{~cm}$. Pakan yang diberikan adalah pakan komersil dengan protein $32,6 \%$; lemak $8,75 \%$; air $8,13 \%$; abu $12,2 \%$; serat kasar $0,96 \%$; BETN $37,4 \%$.

Wadah percobaan adalah bak plastik berukuran $70 \mathrm{~cm}$ x $40 \mathrm{~cm}$ x $35 \mathrm{~cm}$ sebanyak 27 buah. Pada masing-masing perlakuan ditutupi dengan plastik hitam untuk mencegah keluarnya cahaya yang diberi perlakuan. Lampu untuk penyinaran masing-masing perlakuan dipasang $30 \mathrm{~cm}$ dari permukaan air. Pengukuran intensitas cahaya menggunakan lux meter dan aplikasi lama penyinaran setiap perlakuan menggunakan automatic timer. Bak plastik diisi air masingmasing sebanyak $50 \mathrm{~L}$, serta dilengkapi aerasi. Sampling dilakukan pada saat mulai percobaan kemudian ikan ditebar sebanyak 50 ekor setiap bak plastik dan selanjutnya diadaptasikan selama tiga hari pada lingkungan baru. Perlakuan lama penyinaran dan intensitas cahaya yang berbeda mulai dilakukan, selama pemeliharaan ikan diberi pakan secara at satiation dan diberikan pada jam 08.00, 12.00, 16.00 WIB. Wadah percobaan disiphon satu kali setiap pagi untuk menghilangkan feses dan ditambahkan air baru kurang dari $10 \%$.

Rancangan penelitian yang digunakan adalah rancangan acak lengkap faktorial dengan dua faktor perlakuan, yaitu: penambahan lama penyinaran yang berbeda (Faktor A) dan intensitas cahaya yang berbeda (Faktor B). Penambahan lama penyinaran terdiri atas tiga taraf, yaitu: 6 jam (A1), 12 jam (A2), dan 18 jam (A3). Sedangkan penambahan intensitas cahaya terdiri atas tiga taraf, yaitu: 250 lux (B1), 400 lux (B2), dan 550 lux (B3). Dengan demikian, ada sembilan perlakuan, yaitu (A1B1) lama penyinaran enam jam dan intensitas cahaya 250 lux, (A1B2) lama penyinaran enam jam dan intensitas cahaya 400 lux, (A1B3) lama penyinaran enam jam dan intensitas cahaya 550 lux, (A2B1) lama penyinaran 12 jam dan intensitas cahaya 250 lux, (A2B2) lama penyinaran 12 jam dan intensitas cahaya 400 lux, (A2B3) lama penyinaran 12 jam dan intensitas cahaya 550 lux, (A3B1) lama penyinaran 18 jam dan intensitas cahaya 250 lux, (A3B2) lama penyinaran 18 jam dan intensitas cahaya 400 lux, 
(A3B3) lama penyinaran 18 jam dan intensitas cahaya 550 lux. Setiap perlakuan dilakukan tiga kali ulangan.

Pengukuran pertumbuhan ikan dilakukan pada hari ke-10, 20, dan 30 sedangkan pengukuran kualitas air dilakukan pada hari ke-0, 10, 20, dan 30. Setelah ikan dipelihara selama 30 hari, selanjutnya ikan dilakukan uji daya tahan tubuh terhadap arus air dengan cara mengambil semua ikan pada setiap wadah percobaan kemudian dimasukkan ke dalam jaring berukuran $50 \mathrm{~cm}$ x $20 \mathrm{~cm}$ x $20 \mathrm{~cm}$ dengan ketinggian air $10 \mathrm{~cm}$. Selanjutnya diberikan arus air melalui pompa dengan kecepatan arus 1,5 m/dt. kemudian dihitung ikan yang terbawa arus dan ikan yang bertahan atau melawan arus air. Ikan diukur pada hari ke-30 setelah dilakukan uji daya tahan tubuh. Pada akhir penelitian dihitung jumlah pakan yang telah dikonsumsi ikan.

Parameter pengamatan penelitian adalah sintasan [SR = (Jumlah ikan akhir : Jumlah ikan awal) x 100\%], jumlah konsumsi pakan (TFI), rasio konversi pakan $[\mathrm{FCR}=$ (Pakan yang dikonsumsi $\mathrm{x}$ (Biomassa ikan hidup + Biomassa ikan mati) ) $)^{-1}$, laju pertumbuhan spesifik [SGR = (ln biomassa ikan akhir - ln biomassa ikan awal) $\left.\mathrm{x} 100 \mathrm{x} \mathrm{t}^{-1}\right]$, panjang mutlak $[\mathrm{AL}=$ Panjang ikan akhir - Panjang ikan awal], uji daya tahan tubuh ikan terhadap arus air, keragaman ukuran ikan, serta kualitas air (DO, pH, suhu, kesadahan, alkalinitas, amonia). Data SR, TFI, SGR, AL, serta FCR dianalisis ragam menggunakan alat bantu SPSS versi 16.0 dan dilanjutkan dengan uji Duncan untuk mengetahui perbedaan antar perlakuan dengan selang keperca- yaan 95\%. Sedangkan data keragaman ukuran, daya tahan tubuh ikan terhadap arus air, serta kualitas air (DO, pH, suhu, kesadahan, alkalinitas, amonia) dianalisis secara deskriptif.

\section{HASIL DAN BAHASAN}

Pengaruh perbedaan lama penyinaran dan intensitas cahaya terhadap konsumsi pakan, sintasan, laju pertumbuhan spesifik, panjang mutlak, dan konversi pakan pada benih ikan tengadak $B$. schwanenfeldii dapat dilihat pada Tabel 1. Pada umumnya ikan membutuhkan intensitas cahaya yang cukup untuk perkembangan secara normal dan pertumbuhan, namun beberapa spesies dapat berkembang dan tumbuh pada intensitas cahaya yang rendah bahkan tanpa adanya cahaya (Boeuf \& Le Bail, 1999).

Hasil penelitian memperlihatkan adanya pengaruh lama penyinaran dan intensitas cahaya terhadap jumlah konsumsi pakan pada benih tengadak. Jumlah konsumsi pakan terbanyak dari perlakuan A3B3 (lama penyinaran 18 jam dengan intensitas cahaya 550 lux) yaitu $64,44 \pm 5,10 \mathrm{~g}$ tetapi tidak berbeda nyata $(\mathrm{P}>0,05)$ dengan perlakuan $\mathrm{A} 2 \mathrm{~B} 3$ (lama penyinaran 12 jam dengan intensitas cahaya 550 lux) yaitu $63,47 \pm 2,66 \mathrm{~g}$ dan perlakuan A2B1 (lama penyinaran 12 jam dengan intensitas cahaya 250 lux) yaitu 62,68 $\pm 3,97 \mathrm{~g}$; sedangkan jumlah konsumsi pakan terendah pada perlakuan A1B1 (lama penyinaran enam jam dengan intensitas cahaya 250 lux) yaitu 54,61 $\pm 1,80 \mathrm{~g}$. Hal ini diduga bahwa semakin lama penyinaran dan peningkatan intensitas cahaya akan meningkatkan

Tabel 1. Rata-rata jumlah konsumsi pakan (TFI), sintasan (SR), laju pertumbuhan spesifik (SGR), panjang mutlak (AL), dan konversi pakan (FCR) pada benih ikan tengadak B. schwanenfeldii dengan perbedaan lama penyinaran dan intensitas cahaya

Table 1. Average total feed intake (TFI), survival rate (SR), specific growth rate (SGR), absolute length $(A L)$, and feed conversion ratio (FCR) in Tinfoil barb B. schwanenfeldii with different photoperiods and light intensities

\begin{tabular}{lccccc}
\hline \multirow{2}{*}{$\begin{array}{c}\text { Perlakuan } \\
\text { Treatments }\end{array}$} & \multicolumn{5}{c}{ Parameter (Parameters) } \\
\cline { 2 - 6 } & TFI (g) & FCR & SGR (\%) & AL (cm) & SR (\%) \\
\hline A1B1 & $54.61 \pm 1.80^{\mathrm{a}}$ & $2.01 \pm 0.11^{\mathrm{a}}$ & $4.99 \pm 0.26^{\mathrm{a}}$ & $1.16 \pm 0.07^{\mathrm{ab}}$ & $92.67 \pm 7.02^{\mathrm{a}}$ \\
A1B2 & $55.08 \pm 1.62^{\mathrm{a}}$ & $1.96 \pm 0.26^{\mathrm{a}}$ & $5.11 \pm 0.37^{\mathrm{ab}}$ & $1.13 \pm 0.18^{\mathrm{a}}$ & $92.67 \pm 1.15^{\mathrm{a}}$ \\
A1B3 & $55.33 \pm 2.49^{\mathrm{a}}$ & $1.98 \pm 0.18^{\mathrm{a}}$ & $5.07 \pm 0.14^{\mathrm{ab}}$ & $1.20 \pm 0.11^{\mathrm{ab}}$ & $96.00 \pm 4.00^{\mathrm{a}}$ \\
A2B1 & $62.68 \pm 3.97^{\mathrm{b}}$ & $2.16 \pm 0.33^{\mathrm{a}}$ & $5.22 \pm 0.46^{\mathrm{ab}}$ & $1.22 \pm 0.18^{\mathrm{abc}}$ & $96.67 \pm 5.77^{\mathrm{a}}$ \\
A2B2 & $58.32 \pm 3.06^{\mathrm{ab}}$ & $1.94 \pm 0.23^{\mathrm{a}}$ & $5.31 \pm 0.40^{\mathrm{ab}}$ & $1.30 \pm 0.13^{\mathrm{abcd}}$ & $97.33 \pm 4.62^{\mathrm{a}}$ \\
A2B3 & $63.47 \pm 2.66^{\mathrm{b}}$ & $1.91 \pm 0.10^{\mathrm{a}}$ & $5.64 \pm 0.23^{\mathrm{b}}$ & $1.42 \pm 0.18^{\mathrm{cd}}$ & $96.67 \pm 3.06^{\mathrm{a}}$ \\
A3B1 & $60.76 \pm 2.87^{\mathrm{ab}}$ & $2.10 \pm 0.22^{\mathrm{a}}$ & $5.19 \pm 0.28^{\mathrm{ab}}$ & $1.27 \pm 0.04^{\mathrm{abcd}}$ & $96.67 \pm 4.16^{\mathrm{a}}$ \\
A3B2 & $59.67 \pm 4.14^{\mathrm{ab}}$ & $1.89 \pm 0.41^{\mathrm{a}}$ & $5.40 \pm 0.33^{\mathrm{ab}}$ & $1.40 \pm 0.03^{\mathrm{bcd}}$ & $95.33 \pm 1.15^{\mathrm{a}}$ \\
A3B3 & $64.44 \pm 5.10^{\mathrm{b}}$ & $1.99 \pm 0.14^{\mathrm{a}}$ & $5.62 \pm 0.37^{\mathrm{ab}}$ & $1.46 \pm 0.05^{\mathrm{d}}$ & $97.33 \pm 1.15^{\mathrm{a}}$ \\
\hline
\end{tabular}

Nilai dalam kolom yang diikuti huruf yang sama tidak berbeda nyata $(\mathrm{P}>0,05)$ (Values in column followed by the same superscript are not significantly different $(P>0.05))$ 
jumlah konsumsi pakan benih tengadak, dan sebaliknya. Indikator untuk menentukan efektivitas ikan dalam memanfaatkan pakan adalah besar kecilnya nilai konversi pakan. Nilai konversi pakan (FCR) pada semua perlakuan tidak menunjukkan perbedaan yang nyata $(\mathrm{P}>0,05)$ yang berkisar antara 1,89 hingga 2,16 . Hal ini diduga bahwa penyerapan nutrisi pakan yang diberikan pada benih tengadak relatif sama pada semua perlakuan. Menurut Boeuf \& Le Bail (1999), cahaya memengaruhi pertumbuhan ikan juga merangsang laju konsumsi pakan yang pada akhirnya meningkatkan efisiensi pakan.

Laju pertumbuhan spesifik benih ikan tengadak tertinggi pada perlakuan A2B3 (lama penyinaran 12 jam dengan intensitas cahaya 550 lux) yaitu 5,64 $0,23 \%(P<0,05)$. Sedangkan laju pertumbuhan spesifik benih ikan tengadak terendah pada perlakuan A1B1 (lama penyinaran enam jam dengan intensitas cahaya 250 lux) yaitu $4,99 \pm 0,26 \%$. Panjang mutlak tertinggi pada perlakuan A3B3 (lama penyinaran 18 jam dengan intensitas cahaya 550 lux) yaitu $1,46 \pm 0,05 \mathrm{~cm}$; namun tidak menunjukkan perbedaan yang nyata $(\mathrm{P}>0,05)$ dengan perlakuan A2B3 (lama penyinaran 12 jam dengan intensitas cahaya 550 lux) yaitu $1,42 \pm 0,18$ $\mathrm{cm}$. Hasil penelitian ini menunjukkan bahwa terdapat interaksi antara lama penyinaran dengan intensitas cahaya yang memengaruhi pertumbuhan benih ikan tengadak. Pemeliharaan benih tengadak pada semua perlakuan tidak menunjukkan perbedaan yang nyata $(P>0,05)$ terhadap nilai sintasan yang berkisar antara 92,67\% sampai dengan 97,33\%. Lama penyinaran 12 jam dan intensitas cahaya 550 lux lebih baik daripada perlakuan lainnya. Lama penyinaran cahaya pada iklim tropis rata-rata 12 jam, Boeuf \& Le-Bail (1999) intensitas penyinaran minimal diperlukan sehingga ikan dapat membedakan cahaya dari kegelapan, sebagian besar ikan mengikuti ritme alami (diurnal atau musiman) periode cahaya untuk aktivitasnya termasuk ritme pola makan. Pada benih ikan Mirror carp Cyprinus carpio lama penyinaran 24 jam akan meningkatkan pertumbuhan dan efisiensi pakan (Yagci \& Yigit, 2009), juga pada Rainbow trout bila dipelihara dengan lama penyinaran 16 jam (Sonmez et al., 2009; Barimani et al., 2013). Pertumbuhan dan sintasan benih tengadak pada intensitas cahaya 550 lux lebih baik daripada intensitas cahaya 250 lux dan 400 lux. Karakatsouli et al. (2010) pertumbuhan Mirror common carp Cyprinus carpio pada intensitas cahaya 150 lux dan 300 lux tidak signifikan ( $P>0,05)$.

Keragaman bobot dan panjang benih ikan tengadak setelah dipelihara pada perbedaan lama penyinaran dan intensitas cahaya dapat dilihat pada Gambar 1. Keragaman ukuran ikan dapat menunjukkan efektivitas perbedaan lama penyinaran dan intensitas cahaya terhadap pertumbuhan ikan, semakin ke- cil keragaman ukuran ikan maka semakin baik. Selain itu, ukuran ikan terkait dengan harga jual ikan tengadak pada setiap ukuran ikan. Hasil penelitian memperlihatkan perbedaan lama penyinaran dan intensitas cahaya berpengaruh terhadap keragaman bobot benih ikan tengadak. Populasi benih tengadak yang memiliki bobot $80,7 \mathrm{~g}$; terbanyak pada perlakuan A2B3 (lama penyinaran 12 jam dan intensitas cahaya 550 lux) yaitu $45,06 \%$ dan paling sedikit pada perlakuan A1B1 (lama penyinaran enam jam dan intensitas cahaya 250 lux) yaitu $22,02 \%$. Populasi benih tengadak yang memiliki bobot $70,5 \mathrm{~g}$; terbanyak pada perlakuan A1B1 (lama penyinaran enam jam dan intensitas cahaya 250 lux) yaitu 59,34\% sedangkan paling sedikit pada perlakuan A2B3 (lama penyinaran 12 jam dan intensitas cahaya 550 lux) yaitu 32,99\%. Pemeliharaan benih tengadak pada intensitas cahaya 550 lux mengalami pertumbuhan bobot ikan relatif lebih cepat dengan lama penyinaran yang sama daripada intensitas cahaya 250 lux dan 400 lux, dan sebaliknya. Menurut Boeuf \& Le Bail (1999), pada umumnya intensitas cahaya lebih tinggi akan meningkatkan pertumbuhan yang optimal, intensitas cahaya 600-1.300 lux menyebabkan pertumbuhan optimal ikan Seabream.

Populasi benih tengadak setelah dipelihara pada perbedaan lama penyinaran dan intensitas cahaya menyebabkan keragaman panjang badan ikan. Populasi benih tengadak yang memiliki panjang tubuh 8 3,6 cm; terbanyak pada perlakuan A2B3 (lama penyinaran 12 jam dan intensitas cahaya 550 lux) yaitu $37,48 \%$ dan paling sedikit pada perlakuan A1B1 (lama penyinaran enam jam dan intensitas cahaya 250 lux) yaitu $10,95 \%$. Populasi benih tengadak yang memiliki panjang badan $73,0 \mathrm{~cm}$; terbanyak pada perlakuan A1B2 (lama penyinaran enam jam dan intensitas cahaya 400 lux) yaitu $48,07 \%$ dan paling sedikit pada perlakuan A3B3 (lama penyinaran 18 jam dan intensitas cahaya 550 lux) yaitu $19,13 \%$. Populasi benih tengadak dengan lama penyinaran enam jam pertumbuhannya relatif lebih lambat dibandingkan dengan lama penyinaran 12 jam dan 18 jam. Pertumbuhan panjang badan benih tengadak lebih cepat pada intensitas cahaya 550 lux daripada 250 lux dan 400 lux. Keragaman pertumbuhan benih tengadak ini dapat dijelaskan bahwa perilaku makan untuk mendeteksi dan menangkap makanan dipengaruhi oleh intensitas cahaya.

Ikan tengadak merupakan ikan endemik yang berasal dari Kalimantan yang habitatnya di sungai besar dan sungai kecil, salah satunya di Sungai Kapuas. Daerah estuari sungai Kapuas merupakan daerah yang sangat kompleks karena adanya pengaruh seperti sapuan arus, hempasan ombak dan pasang surut laut. Menurut Jumarang et al. (2011), pergerakan massa air 

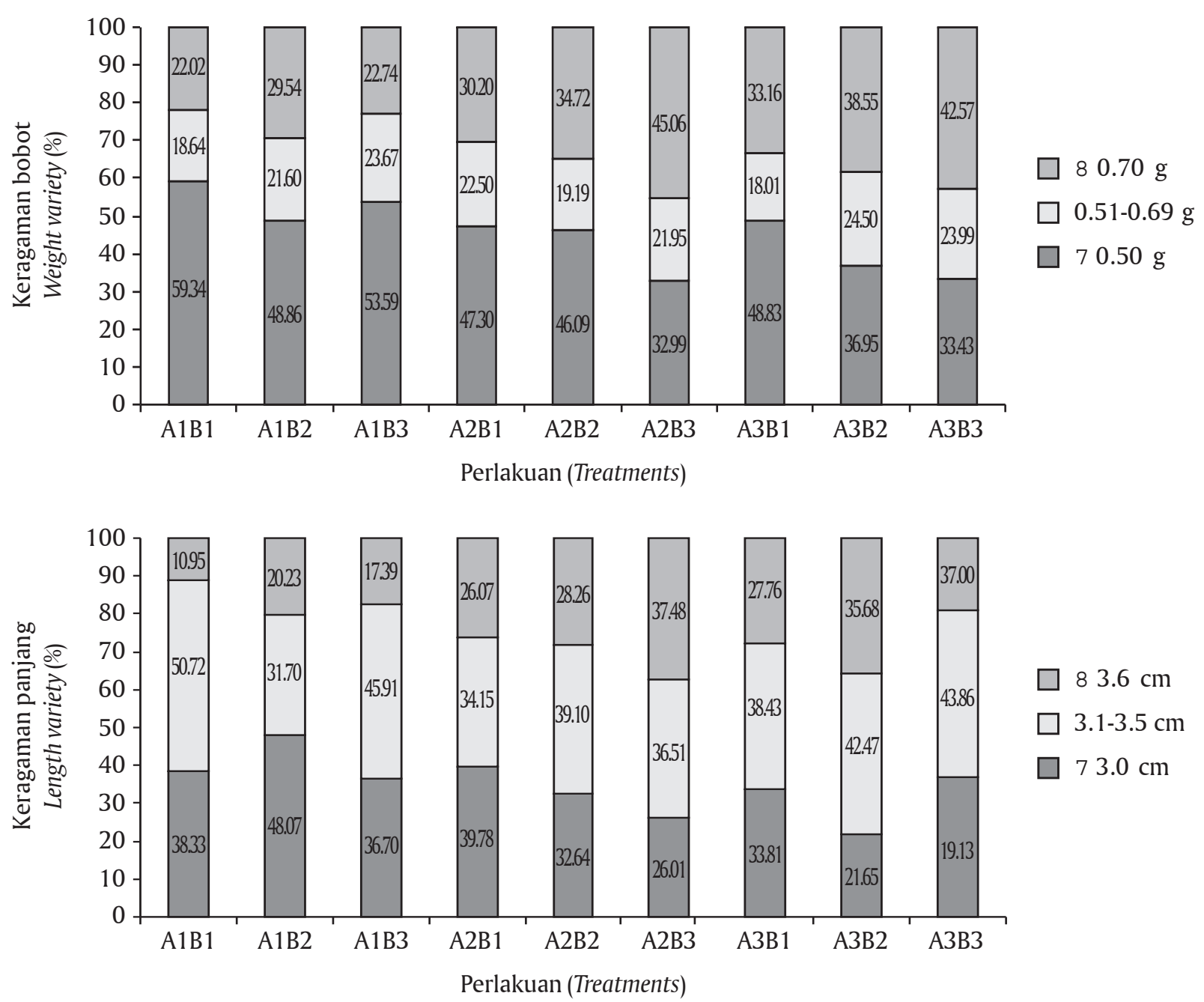

Gambar 1. Tingkat keragaman bobot (atas) dan keragaman panjang (bawah) pada benih tengadak setelah dipelihara dengan perbedaan lama penyinaran dan intensitas cahaya

Figure 1. Weight variety level (top) and length variety (bottom) in juvenile Tinfoil barb after reared in different photoperiods and light intensities

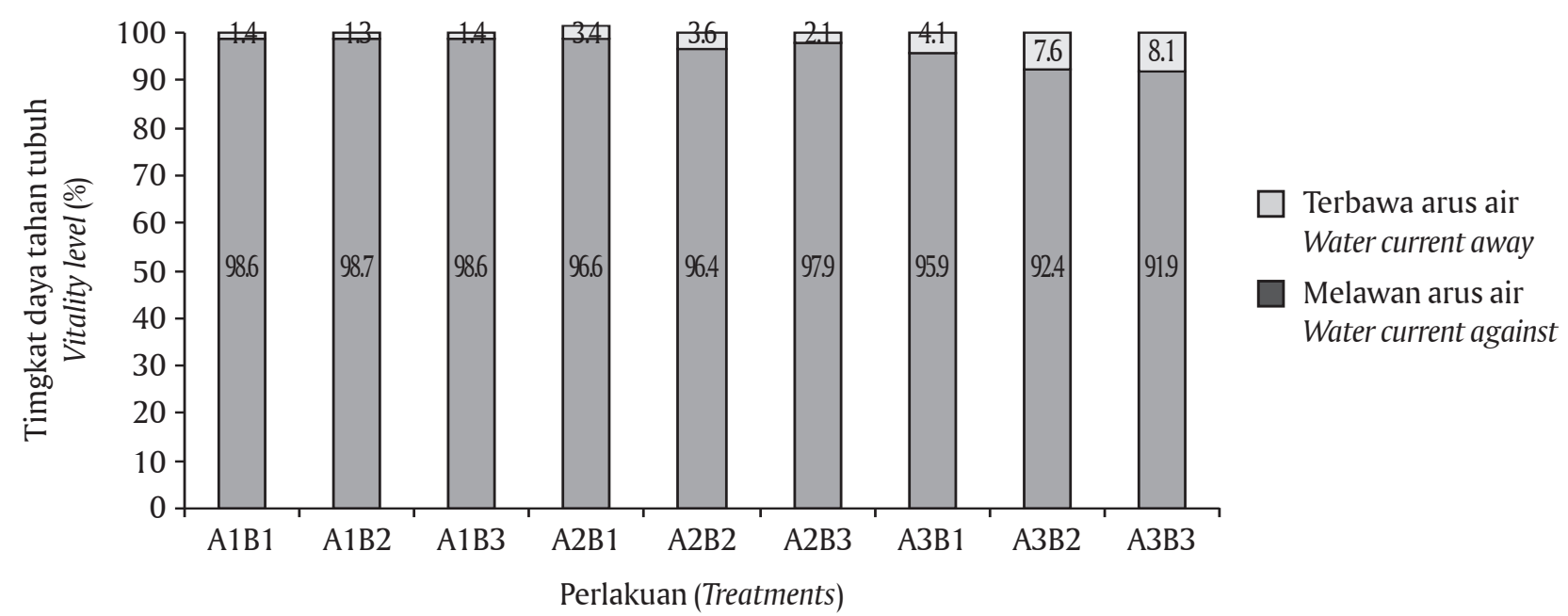

Gambar 2. Tingkat daya tahan tubuh benih tengadak terhadap arus air setelah dipelihara dengan perbedaan lama penyinaran dan intensitas cahaya

Figure 2. Vitality level of juvenile Tinfoil barb on water current after reared in different photoperiods and light intensities 


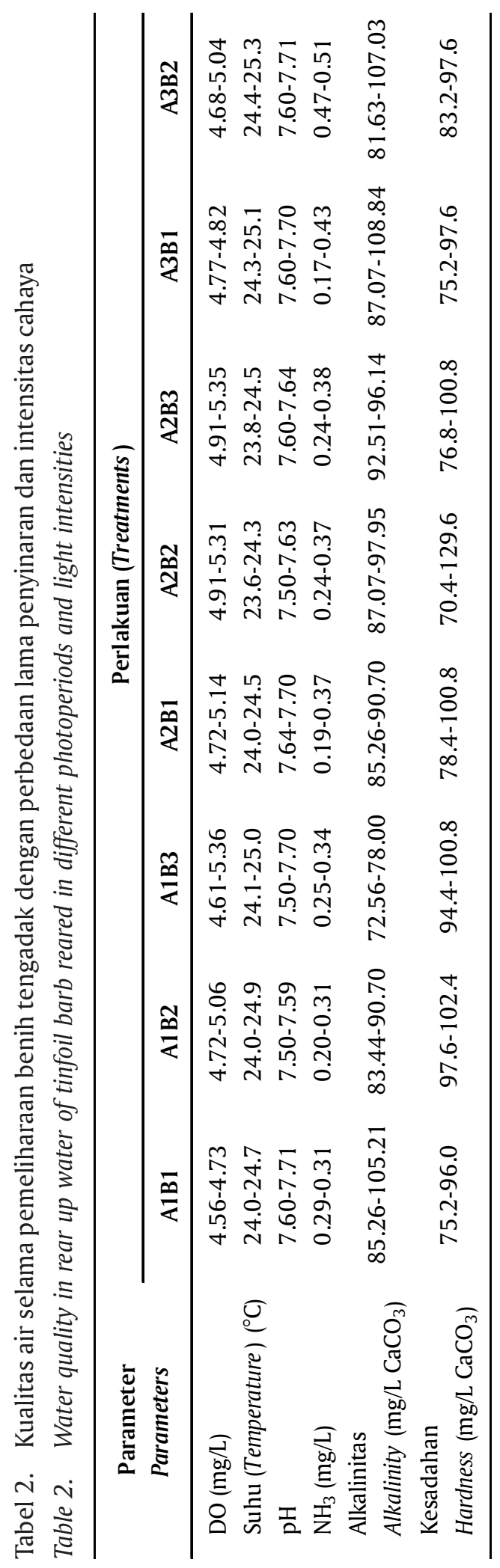


Sungai Kapuas Kalimantan Barat pada kondisi purnama lebih tinggi dibandingkan saat perbani dengan kecepatan arus 0,05-0,7 m/dt., sedangkan berdasarkan hasil penelitian Agustini et al. (2013) kecepatan arus Sungai Kapuas berkisar 0,48-0,56 m/dt.

Hasil pengujian daya tahan tubuh benih ikan tengadak terhadap kecepatan arus memperlihatkan benih yang paling banyak terbawa arus pada perlakuan A3B3 (lama penyinaran 18 jam dan intensitas cahaya 550 lux) (Gambar 2). Hal ini memperlihatkan bahwa semakin lama penyinaran dengan intensitas cahaya semakin tinggi akan menurunkan daya tahan tubuh ikan. Menurut Boeuf \& Le Bail (1999), intensitas cahaya yang intensif dapat menyebabkan stres bahkan kematian. Hasil penelitian Setiadi et al. (2002) kematian larva Red spotted grouper Epinephelus akaara semakin tinggi seiring dengan peningkatan intensitas cahaya dan intensitas cahaya terbaik pada 500 lux.

Kualitas air selama pemeliharaan benih tengadak dapat dilihat pada Tabel 2. Berdasarkan hasil pengukuran kualitas air media pemeliharaan selama penelitian masih layak untuk kehidupan dan pertumbuhan benih tengadak.

\section{KESIMPULAN}

Pertumbuhan dan sintasan benih ikan tengadak yang terbaik bila dipelihara pada kombinasi lama penyinaran 12 jam dan intensitas cahaya 550 lux.

\section{DAFTAR ACUAN}

Agustini, T., Jumarang, M.I., \& Ihwan, A. (2013). Simulasi pola sirkulasi arus di muara Kapuas Kalimantan Barat. Jurnal Prisma Fisika, I, 33-39.

Barimani, S., Kazemi, M.B., \& Hazaei, K. (2013). Effects of different photoperiod regimes on growth and feed conversion rate of young Iranian and French Rainbow Trout (Oncorhynchus mykiss). World Applied Sciences Journal, 21, 1440-1444.

Boeuf, G., \& Le Bail, P.Y. (1999). Does light have an influence on fish growth?. Aquaculture, 177, 129152.

Boyd, C.E. (1988). Water quality in warmwater fish ponds. Fourth Printing. Auburn University Agricultural Experiment Station. Alabama, 359 pp.

Erguin, S., Yigit, M., \& Türker, A. (2003). Growth and feed consumption of young Rainbow Trout (Oncorhynchus mykiss) exposed to different photoperiods. The Israeli Journal of Aquaculture, 55, 132138.

Fujaya, Y. (2004). Fisiologi ikan dasar pengembangan teknologi perikanan. PT. Rineka Cipta. Jakarta.

Huwoyon, G.H., Kusmini, I.I., \& Kristanto, A.H. (2010). Keragaan pertumbuhan ikan tengadak alam (hi- tam) dan tengadak budidaya (merah) (Barbonymus schwanenfeldii) dalam pemeliharaan bersama pada kolam beton. Prosiding Forum Inovasi Teknologi Akuakultur: Pusat Penelitian dan Pengembangan Perikanan Budidaya. Jakarta, hlm. 501-505.

Jumarang, M.I., Muliadi, Ningsih, N.S., Hadi, S., \& Martha, D. (2011). Pola sirkulasi arus dan salinitas perairan estuary Sungai Kapuas, Kalimantan Barat. Jurnal Positron, I, 36-42.

Karakatsouli, N., Papoutsoglou, E.S., Sotiropoulos, N., Mourtikas, D., Martinsen, T.S., \& Papoutsoglou, S.E. (2010). Effect of light spectrum, rearing density and light intensity on growth performance of scaled and Mirror Common Carp Cyprinus carpio reared under recirculating system conditions. Aquacultural Engineering, 42, 121-127.

Karlsen, O., Norberg, B., Kjesbu, O.S., \& Taranger, G. L. (2006). Effects of photoperiod and exercise on growth, liver size, and age at puberty in farmed Atlantic Cod (Gadus morhua L.). ICES Journal of Marine Science, 63, 355-364.

Martin, P., Rancon, J., Segura, G., Laffont, J., Boeuf, G., \& Dufour, S. (2012). Experimental study of the influence of photoperiod and temperature on the swimming behaviour of hatchery-reared Atlantic Salmon (Salmo salar L.) smolts. Aquaculture, p. 19.

Mustapha, M.K., Okafor, B.U., Olaoti, K.S., \& Oyelakin, O.K. (2012). Effects of three different photoperiods on the growth and body coloration of juvenile African Catfish (Burchell). Arch. Pol. Fish., 20, 55-59.

Prayogo, N.A., Wijayanti, G.E., Murwantoko, Kawaichi, M., \& Astuti, P. (2012). Effect of photoperiods on melatonin levels, the expression of cGnRH-II and $s G n R H$ genes and estradiols level in Hard-Lipped Barb (Osteochilus hasselti C.V.). Global Veterinaria, 8, 591-597.

Sarkar, A., \& Upadhyay, B. (2011). Influence of photoperiod and temperature on reproduction and gonadal maturation in Gold fish: Carassius auratus. International Journal of Applied Biology and Pharmaceutical Technology, 2, 352-358.

Setiadi, E., Tsumura, S., \& Yamaoka, K. (2002). Effects of water color and light intensity on water surface tension-related deaths in larval stage of the Red spotted grouper, Epinephelus akaara. Suisanzoshoku, 51, 81-85.

Sonmez, A.Y., Hisar, O., Hisar, S.A., Alak, G., Aras, M.S., \& Yanik, T. (2009). The effects of different photoperiod regimes on growth, feed conversion rate and survival of Rainbow Trout (Oncorhynchus mykiss) fry. Journal of Animal and Veterinary Advances, 8, 760-763. 
Srivastava, S., \& Choudhary, S.K. (2010). Effect of artificial photoperiod on the blood cell indices of the Catfish, Clarias batrachus. Journal of Stress Physiology \& Biochemistry, 6, 22-32.

Vardar, H., \& Yildirim, S. (2012). Effects of long-term extended photoperiod on somatic growth and husbandry parameters on cultured Gilthead Sea bream (Sparus aurata, L.) in the net cages. Turkish Journal of Fisheries and Aquatic Sciences, 12, 225231.

Widiyati, A., Yosmaniar, \& Nurdin, M. (2012). Pende- deran ikan tengadak (Barbonymus schwanenfeldii) dengan kepadatan tebar berbeda di perairan Sungai Mempawah Kabupaten Pontianak (Kalimantan Barat). Prosiding Seminar Nasional Perikanan. Sekolah Tinggi Perikanan. Jakarta, hlm. 2327.

Yagci, D.D., \& Yigit, M. (2009). Influence of increased photoperiods on growth, feed consumption and survival of juvenile Mirror Carp (Cyprinus carpio Linnaeus, 1758). Journal of Fisheries Sciences.com, 3, 146-152. 